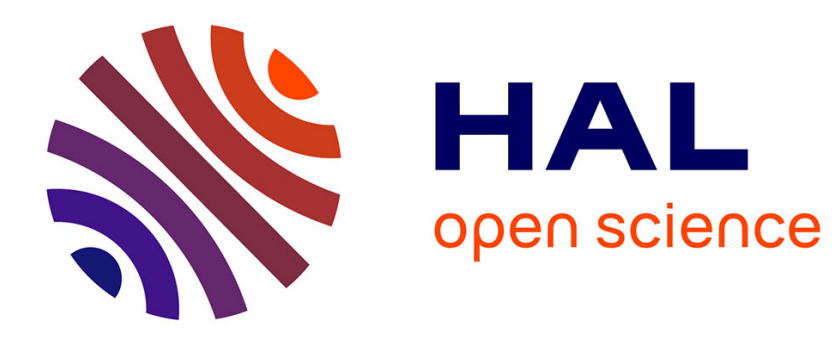

\title{
The history of professional road cycling
}

Jean-François Mignot

\section{To cite this version:}

Jean-François Mignot. The history of professional road cycling. The Economics of Professional Road Cycling, , pp.7-31, 2016, 978-3-319-22312-4. 10.1007/978-3-319-22312-4 . halshs-01326719

\section{HAL Id: halshs-01326719 \\ https://shs.hal.science/halshs-01326719}

Submitted on 5 Jun 2016

HAL is a multi-disciplinary open access archive for the deposit and dissemination of scientific research documents, whether they are published or not. The documents may come from teaching and research institutions in France or abroad, or from public or private research centers.
L'archive ouverte pluridisciplinaire HAL, est destinée au dépôt et à la diffusion de documents scientifiques de niveau recherche, publiés ou non, émanant des établissements d'enseignement et de recherche français ou étrangers, des laboratoires publics ou privés. 


\section{Chapter 1: The history of professional road cycling ${ }^{1}$}

\section{Jean-François Mignot}

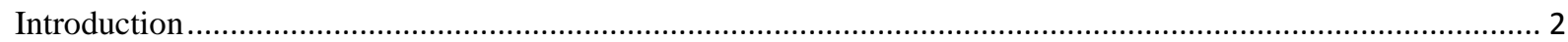

1. Economic aspects of professional road cycling: from local races to global sport events ............................ 2

2. The institutional organization of professional road cycling: the historical role of the International Cycling Union...

3. The show of bicycle races: a century of 'Grand Tours'

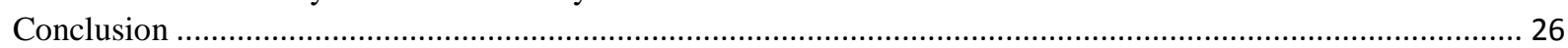

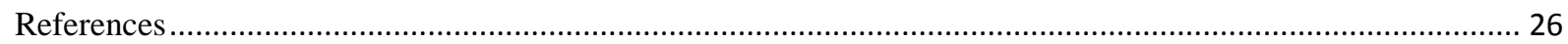

\footnotetext{
${ }^{1}$ I wish to thank Céline Goffette, Delphine Goffette and Davide Togni for enabling me to get into contact with Castellano Carmine, who kindly communicated his quantitative data on the Giro d'Italia.
} 


\section{Introduction}

Why did cycling become professional as early as the late $19^{\text {th }}$ century, while other sports (such as rugby) and other sport events (such as the Olympic Games) remained amateur until the 1980s? Why are the organizers of the most important cycling races private companies? To what extent have bicycle races changed since the late $19^{\text {th }}$ century? And how does cycling reflect long-term economic changes? The history of professional road cycling helps to answer these questions and to understand many related phenomena.

This chapter provides a long-term historical perspective on (1) professional road cycling's economic agents, i.e. the public, race organizers, team sponsors and riders, and the relationships among them; (2) cycling's governing body, the International Cycling Union; and (3) professional cycling's final product, i.e. the show of bicycle races. The chapter focuses more specifically on the history of male professional road cycling in Western Europe since the late- $19^{\text {th }}$ century. It is founded on both an analysis of quantitative time series of the most important races and a review of the existing literature on the history of professional cycling, whether economic history (Reed 2003; McKay 2011b; Mignot 2014), institutional history (Dauncey and Hare 2003), cultural history (Vigarello 1997; Thompson 2006) or sport history (Chany and Penot 1997; Chany and Cazeneuve 2003; McGann and McGann 2006-2008; McGann and McGann 2011-2012; Fallon and Bell 2013).

\section{Economic aspects of professional road cycling: from local races to global sport events}

Since the late $19^{\text {th }}$ century, the economic sector of professional cycling includes four main types of agents. The public is willing to pay and/or to watch advertisements in order to be able to follow the developments of a bicycle race. Sport event organizers are willing to pay for the race's logistics and prize money in order to sell newspapers, advertising space on the race and TV broadcast rights; race organizers may also auction off the race's route to the highest bidding host cities. Various team sponsors are willing to pay riders a wage (and perhaps to pay organizers a price) to advertise for their products on the race. Finally, riders are willing to spend energy and advertise for their sponsor to earn a wage and win the race's prize money. How have long-term socioeconomic trends that occurred during the $20^{\text {th }}$ century, such as increasing income and leisure time, the diffusion of consumption goods such as television and 
the liberalization of markets, affected these agents and led to the emergence, the development and crises and the globalization of professional road cycling?

\subsection{The emergence of professional road cycling (1890s-mid-1950s)}

Bicycles as we know them - with a mobile handlebar, two equal-sized wheels, pedals, a chain, tires and then derailleur gears - were introduced from the 1880s on. Back then, bicycles symbolized speed and modernity (Gaboriau 1995). As Western Europeans' real income increased (in Belgium, the Netherlands, France, Spain and Italy the GDP per capita multiplied by 1.8 from 1890 to 1950 (Maddison 2004)) and bicycles' price plummeted, bicycle sales skyrocketed. While in 1890 there were fewer than 0.5 bicycles per 100 French people, in the early 1950s there were close to 30 (Insee 1952). Additionally, as employees' annual working time decreased (it was divided by 1.3 from 1890 to 1950 (Maddison 2004)), newspaper sales increased. This context led sport newspapers and bicycle companies to invest in the organization of bicycle races, i.e. to finance races' operating costs and prizes, in order to increase their own profits.

Although newspapers organized the first officially recorded road races as early as the late 1860 s, until the 1880 s most of the races were organized in velodromes, where they could charge entry fees (table 1.1). From the 1890s, newspapers started organizing races on public roads to show bicycles enabled to cover great distances and to boost their sales and their advertisement revenue. Most of these French, Belgian and Italian annual races from one city to another, now called "classics," were run on distances ranging from 250 to $400 \mathrm{~km}$, which means that the best riders often had to race for more than 10 hours to complete the race. Bordeaux-Paris and Paris-Brest-Paris, both created in 1891 (but discontinued in 1988 and 1951, respectively) even required the best riders to keep riding for more than 25 and 70 hours. No wonder journalists described these races as epic fights between modern heroes. Newspapers organized cycling, not soccer or boxing competitions, because a roadside spectator can watch a road race for a few seconds only. As a result, cycling fans demand more information and want pictures of the race, enabling newspapers to increase their circulation. 
Table 1.1 The first European road races and their organizers

\begin{tabular}{ccccc}
\hline Race & Creation & Location & Distance & (First) Organizer \\
\hline Paris (Saint-Cloud)* & 1868 & France & 1.2 & Michaux bicycle company \\
Paris-Rouen* & 1869 & France & 123 & Le Vélocipède illustré \\
Bordeaux-Paris & 1891 & France & 572 & Véloce-Sport \\
Paris-Brest-Paris & 1891 & France & 1,200 & Le Petit Journal \\
Liège-Bastogne-Liège & 1892 & Belgium & 250 & L'Expresse \\
Paris-Brussels & 1893 & France \& Belgium & 407 & La Bicyclette \\
Paris-Roubaix & 1896 & France & 280 & Roubaix velodrome builders \\
Paris-Tours & 1896 & France & 250 & Paris-Vélo \\
Tour de France & 1903 & France & 2,428 & L'Auto \\
Tour of Lombardy & 1905 & Italy & 230 & La Gazzetta dello Sport \\
Milan-San Remo & 1907 & Italy & 288 & La Gazzetta dello Sport \\
Tour of Italy & 1909 & Italy & 2,448 & La Gazzetta dello Sport \\
Tour of Flanders & 1913 & Belgium & 324 & Sportwereld \\
Tour of Spain & 1935 & Spain & 3,425 & Informaciones \\
La Flèche wallonne & 1936 & Belgium & 263 & Les Sports \\
\hline
\end{tabular}

*These races were run on machines with pedals but no chain, let alone tires.

Moreover, from the 1900s, certain newspapers started organizing stage races, i.e. road races run over several days. In 1903, Henri Desgrange's French newspaper L'Auto created the Tour de France, a race which included six stages over three weeks, totaling a staggering 2,428 kilometers. It was such a success that L'Auto's main competitor, Le Vélo, went bankrupt in 1904. In 1909, Italian newspaper La Gazzetta dello Sport, which was headed by Armando Cougnet, a journalist who had followed some of the early editions of the Tour, pre-empted the Corriere della Sera's decision to organize a stage race and created the Giro d'Italia (hereafter often shortened to Giro). Once again it was such a success that in 1913 the Gazzetta went from a thrice-monthly to a daily newspaper. And in 1935, Juan Pujol's Spanish newspaper Informaciones created the Vuelta a España (hereafter often shortened to Vuelta). Although free for spectators, these great three-week stage races boosted their organizers' profits by increasing their circulation and by generating additional revenue sources: cities were willing to pay race organizers to host certain stages, and various companies were ready to sponsor the race to advertise their brand on the competition's route. Since 1930 and 1933, respectively, the Tour and the Giro include a publicity caravan, i.e. dozens of vehicles preceding the riders by a few minutes and distributing product samples to spectators. Today, these three-week stage races, generally called the "Grand Tours", are the most popular, prestigious and lucrative bicycle races in the world and they are still organized by media companies. The Tour de France has been organized by L'Auto (1903-1940) and by both L'Équipe and Le Parisien libéré (1947-1965), which since 1965 are owned by Amaury Sport Organisation 
(ASO), still the current Tour de France organizer. The Giro d'Italia has been organized by $L a$ Gazzetta dello Sport, which is owned by RCS Media Group since 1977. The Vuelta a España has been organized by Informaciones (1935-1942), Ya (1945-1950), El Correo Español - El Pueblo Vasco (1955-1978) and Unipublic (since 1979).

While newspapers organized the races, bicycle and tire companies sponsored the teams of riders, i.e. they paid for their food and accommodation so that they ride their material, prove its quality and promote their brand through logos on their jerseys and caps. The French tire company Michelin sponsored Charles Terront as early as the 1891 Paris-Brest-Paris, which he won. Among the most famous bicycle companies which sponsored riders are Tour winners Peugeot, Alcyon and Automoto, and Giro winners Bianchi and Legnano. Bicycle companies sponsored riders but rarely organized races themselves because the public would have suspected them of manipulating the race to advertise their brand (Calvet 1981).

Even though certain champions raced in sponsored teams and had a fixed annual wage, most professional riders had no sponsor. They were called indépendants in French or isolati in Italian and they had no wage: all their income came from their race earnings. This is how, as early as the late $19^{\text {th }}$ century, cycling became a professional sport. Until the 1920 s, the bigger part of a rider's income came from his race winnings. His fixed annual wage was relatively low, if there was any. French riders' wages were particularly low after the First World War (1919-1921), because the few remaining bicycle companies were able to cartelize the demand for riders and restrict the wages. From the 1930s (the 1930 Tour and the 1932 Giro), races started to be broadcast on the radio and fans could follow the race live and hear the voices of their champions. As bicycle races' popularity grew, so did riders' incomes. While sponsors had to offer better wages to recruit the greatest champions, race organizers had to increase the race winnings to make it in the champions' interest to both participate in their race and fight for victory.

\subsection{The development and crises of professional road cycling (mid-1950s-mid-1980s)}

As Western Europeans' real income increased quickly (the GDP per capita was multiplied by 4.6 from 1950 to 2000 (Maddison 2004)) and Europe urbanized, people bought modern motorcycles rather than bicycles. As a consequence, bicycle companies started to reduce their 
investments in cycling teams and professional riders' fixed annual wages decreased. This made it in the riders' interest to look for new sponsors from outside of the bicycle industry. In 1954, Italian champion Fiorenzo Magni was the first rider who chose to be sponsored by an “extra-sportif” company (Nivea). While bicycle companies' control of cycling sponsorship eroded, they tried to make it illegal for extra-sportifs to sponsor teams, and in France they also garnered the support of race organizers, who feared that extra-sportifs' investments in sponsorship might decrease their advertisement in newspapers. Extra-sportif sponsors prevailed, though, and to this day they are the main sponsors of cycling teams.

\section{Tour de France's national teams}

Since the late $19^{\text {th }}$ century, sponsored riders and teams ride the Grand Tours, the classics and the other races in the name of their sponsor. The only races in which they compete in the name of their country are the Road Cycling World Championships and the Olympic Games' competitions. Another exception, though, has been the Tour de France, which was not run among sponsored teams but among national teams from 1930 to 1961, and also in 1967 and 1968.

Why did the Tour organizers decide in 1930 to exclude sponsored teams from the race? In the 1920s the growing concentration of firms in the bicycle industry enabled certain companies to invest in team sponsorship much more than others. Their teams hired all of the best riders and were even willing to pay other teams to secure victory, so much so that the race lost much of its appeal. The Alcyon team won the 1927 Tour; it won first, second and third place in 1928; and it won again in 1929. This is why, even though sponsored teams were an important source of income for the Tour organizers, they were replaced in 1930 with national teams, which were supposed to be both more equal and less willing to fix the race. The Tour organizers not only banned sponsored teams until 1962, they also banned commercial advertising on riders' national clothing until 1956.

Why then did the Tour organizers decide in 1962 to admit sponsored teams back? In the mid-1950s, as bicycle companies stopped sponsoring teams, they were replaced by companies from various other sectors of the economy. The difference between sponsors from the bicycle industry and sponsors from other sectors is that for the latter riders' jerseys, not bicycles, are the main advertising element. Therefore, the extra-sportifs could not advertise for their products on the Tour, one of the very few races where teams and jerseys (and caps) represented countries instead of private companies. These new commercial sponsors pressured the Tour organizers to replace national teams with sponsored teams. They refused that the most popular champions they were hiring all year long, be included in any of the Tour's national teams. In 1962, the Tour organizers finally gave in and replaced national teams with privately sponsored teams.

As Western European employees' annual working time decreased (it was divided by 1.4 from 1950 to 2000 (Maddison 2004)) and people spent more and more time watching TV, newspapers found bicycles races less and less profitable to organize. Races increased organizers' newspapers' circulation less than before, if only because races were also recalled by competing newspapers. Moreover, races yielded few TV broadcast rights, both because most TV channels were still public, which means they did not have to compete against each 
other to broadcast the races, and because compared to stadium sports of limited duration, bicycle races were hard to broadcast live (see chapter 5). Although the Grand Tours had been filmed as early as the 1920 s to be shown in movie theaters, and from the 1950s parts of them were televised live, the live TV broadcasting of stages long remained problematic. While in the 1970s the Spanish television still wanted to charge teams for showing publicity on their jerseys, as late as the early 1980s it broadcasted only 15 minutes of the Vuelta a day. As a consequence, most race organizers were in deep financial troubles in the 1970s and early 1980s. Moreover, races' prize money decreased. For instance, while in 1955 the Tour de France offered the mean rider the equivalent of 5,550 20085,9232013 euros, in 1980 it offered only 4,437 20084,7352013 euros and riders still had to share them with their mechanics and doctors. Race organizers' financial crisis led them to modify certain aspects of races: "split stages" enabled them to multiply the number of cities that paid them to host the race, "transfers" from one city to another enabled them to select only the best-paying cities, countless secondary prizes enabled them to multiply sponsors, etc.

Although riders' wages and prize winnings suffered a decline from the mid-1950s to the mid1980s, their overall labor incomes did not decrease. Indeed, while the European public had increasing income and leisure time but still few households had TV sets, people were willing to pay to take pictures of champions, shake their hands and have them sign autographs. This is why many small cities organized so-called criteriums, i.e. short one-day road races on a local circuit which paid riders to participate, meet their fans and sometimes to let a predetermined rider win (McKay 2011a). Until the mid-1980s, criteriums' appearance fees provided the majority of a rider's annual income, which is why certain Grand Tour champions like Jacques Anquetil did not ride the classics. They rode the Grand Tours to become or stay famous and the criteriums to earn money. From the early 1950s, starting with Fausto Coppi in 1949, superstars usually gave their teammates all of their Grand Tours or classics' prize winnings, so as to make it in their interest to sacrifice for them. Superstars more than made up for these losses in the numerous, well-paid criteriums which invited the winners of the greatest races. Criteriums were such an important income source that riders hired agents to place them in these races. However, these agents (for instance Frenchmen Daniel Dousset and Roger Piel and Belgian Jean van Buggenhout) became so influential that they gained considerable power over riders (McKay 2011). Agents were even able to influence races' outcomes. For instance, in the 1959 Tour de France, Jacques Anquetil and Roger Rivière conspired to have Federico Bahamontes beat Henry Anglade, partly because both Anquetil and Rivière had the same 
agent as Bahamontes (Daniel Dousset) but not the same as Anglade (Roger Piel), and letting Anglade win would have increased his agent's bargaining power against criterium organizers and thus increased all of his riders' appearance fees, to the detriment of Anquetil and Rivière. The role of agents in cycling is discussed more in detail in chapter 9.

Despite their increasing incomes, most riders were still from peasant or working-class origins (Thompson 2006, pp. 267-268; see also Juan Antonio Bardem's 1955 movie "Death of a Cyclist"). Some riders migrated to higher-income countries. This was the case for several Spanish riders: 1957 and 1959 Milan-San Remo winner Miguel Poblet moved to Italy, while 1959 Tour winner Federico Bahamontes, 1959 Vuelta winner Antonio Suárez and 1961 Vuelta winner Angelino Soler migrated to France. After retiring, many riders opened bars or became bicycle sellers.

\subsection{The globalization of professional road cycling since the mid-1980s}

As transportation and information costs decreased over Europe and European markets integrated, it became in the interest of both race organizers and sponsors to globalize cycling. For instance, since the 1980s there are so many Dutch people who go to L'Alpe d'Huez on the Tour de France that it became called the Dutch people's mountain. More importantly, while the Grand Tours' routes had long remained centered on a single country, race organizers diversified their routes, which usually increases TV audience in each of the visited countries (Van Reeth 2013). Although the 1907 Tour and the 1920 and 1951 Giri had already visited Switzerland and the 1955 Vuelta had visited France, after the Second World War several Grand Tours have had their first stage abroad. The 1954 Tour started in Amsterdam (partly to nip the idea of a "Tour of Europe" in the bud), the 1973 Giro departed from Verviers, Belgium and visited five countries other than Italy, and the 1997 Vuelta started from Lisbon, which hosted the 1998 World's Fair. In honor of the Maastricht Treaty, which created the European Union, the 1992 Tour de France started in Spain and visited a record total of seven countries: France, Spain, Belgium, the Netherlands, Germany, Luxembourg and Italy.

Moreover, while cycling teams had long been formed mostly of riders from one country and teams rode primarily in their own country, the nationalities of Grand Tour participants diversified over the years. And while race organizers had long tried to attract sponsors from their own country, they came to attract more foreign sponsors too. As a result, most of the 
Grand Tours' participants are foreigners since the 1930s in the Tour de France, since the 1960s in the Vuelta a España, and since the 1990s in the Giro d'Italia. While the Giro organizers have long favored Italians and thus deterred foreigners from participating, the Vuelta organizers were eager to attract foreigners to increase the prestige of their race and secure their position in the cycling calendar. As can be seen from figure 1.1, since the 2000s, around $75 \%$ of Grand Tour riders come from outside the country where the race is run, more and more of them from countries or continents where professional cycling does not have a long tradition: Colombia, Eastern Europe, America or Oceania. While the first foreign winners of the Grand Tours were Luxembourg François Faber in the Tour (1909), Belgian Gustaaf Deloor in the Vuelta (1935) and Swiss Hugo Koblet in the Giro (1950), the first nonEuropean winners came much later: the American Greg LeMond (1986 Tour), the Colombian Lucho Herrera (1987 Vuelta), the Russian Evgueni Berzin (1994 Giro) and the Australian Cadel Evans (2011 Tour). It should be noted that although bicycle races have globalized, each tries to keep its own identity and celebrate its own history. For instance, for its $100^{\text {th }}$ anniversary (2003), the Tour went through all of the first edition's host cities, while for its $100^{\text {th }}$ anniversary (1996) La Gazzetta dello Sport, which was created to cover the first Olympic Games of the modern era, had the Giro start in Athens, Greece. In chapter 14 globalization in professional road cycling is analyzed in detail.

Fig. 1.1 Share of 'foreign' participants in the 'Grand Tours' (1903-2013)

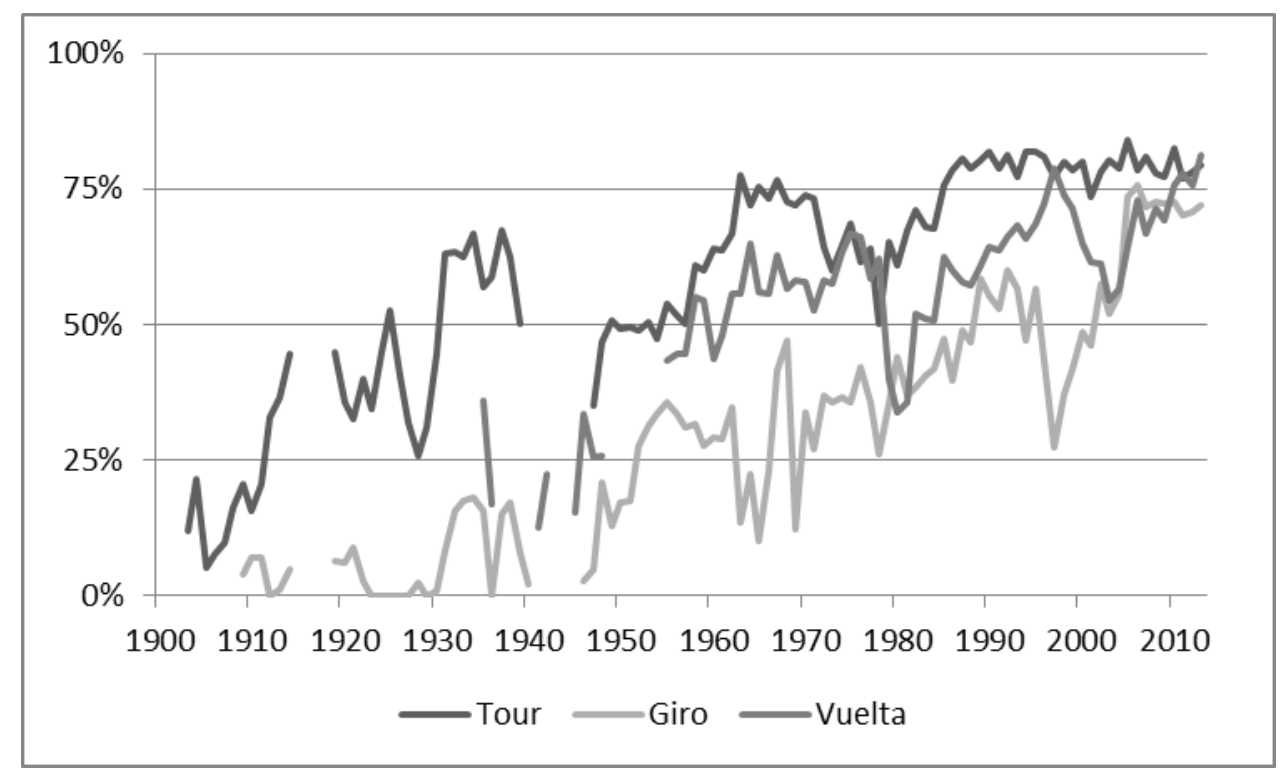

Sources: ASO (Tour de France); RCS Sport and Castellano Carmine (Giro d'Italia); Unipublic (Vuelta a España). 
As technological advances enabled TV channels to increase the quality and duration of the live broadcast of cycling races, audiences grew, which increased the economic value of cycling sponsorship and also sponsors' willingness to pay riders higher wages (Sandy et al. 2004). More importantly still, as European TV markets were liberalized in the 1980s, many public and private channels started to compete with each other to broadcast bicycle races and for a small number of top cycling races organizers' TV broadcasting rights skyrocketed (Bolotny and Bourg 2009). For instance, from 1980 to 2000 the Tour de France's TV broadcast rights increased 65 -fold, enabling the Tour organizers' budget to increase tenfold (from 5.3 to 53 million euros, in 2013 euros). Nowadays, the Tour de France is broadcast in more than 170 countries worldwide.

Fig. 1.2 Tour de France's prize pool, 1903-2013 (2013 euros)

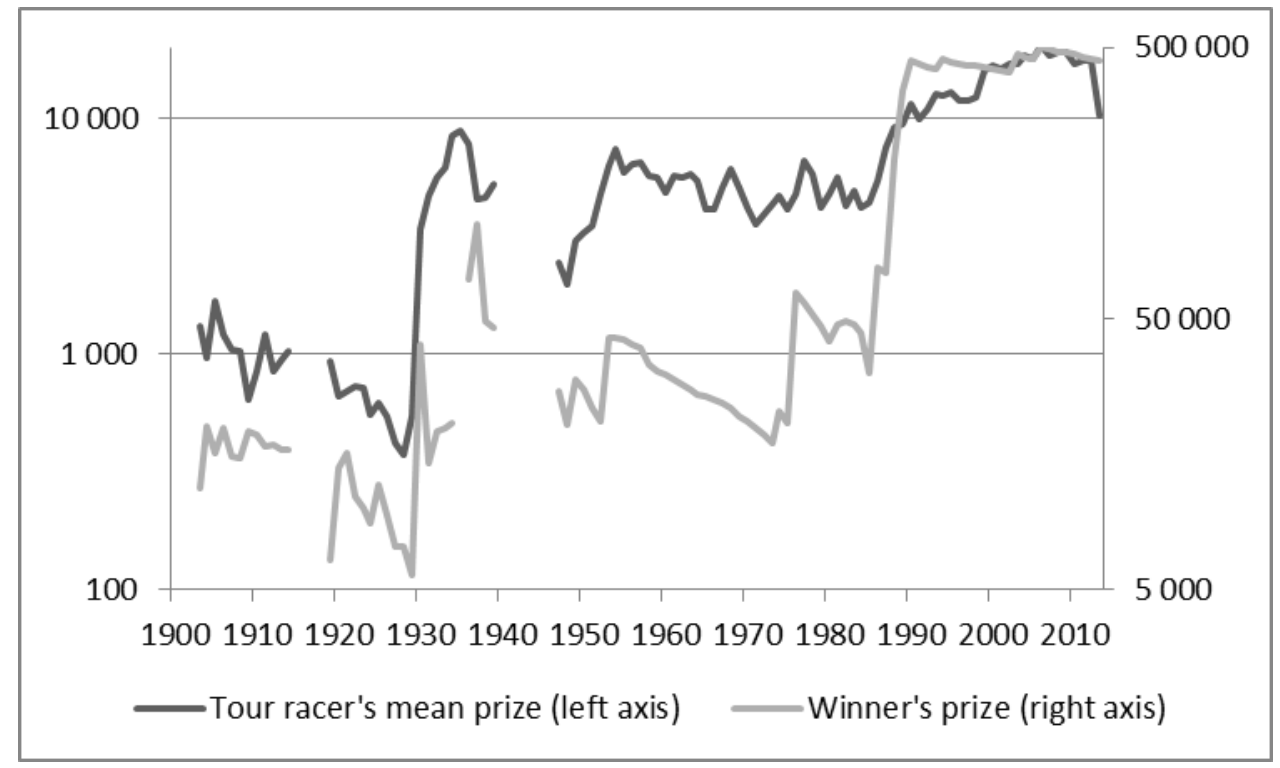

Source: A.S.O. and Augendre 2013.

Since the mid-1980s, riders' incomes have been increasing. Indeed, although in cycling there is still no redistribution of TV revenue to teams, the increased media coverage made companies more willing to pay riders high fixed wages. This is especially true for those few cyclists with the highest marginal productivity in terms of media coverage, which implies that the wages that have been increasing the most are those of cycling's superstars (Rosen 1981). Races' cash prizes (the riders' variable wages) have been increasing too, as can be seen from figure 1.2. For instance, from 1985 to 2010, the Tour de France rider's mean cash prize (total prize pool divided by the number of participants) went from 4,096 to $15,57120084,371$ to 16,6172013 euros. Over the same period, the Tour winner's cash prize went from 29,465 to 
391,182 2008 -31,445 to 417,469 euros (Mignot 2014). To this day, the Tour remains the world's best paid bicycle race. Although certain races' prizes may have increased at a higher rate than the Tour's, their prizes are still much lower.

\section{The institutional organization of professional road cycling: the historical role of the International Cycling Union}

As early as the late $19^{\text {th }}$ century, when professional cycling emerged separately in different European countries and the United States, this decentralized organization raised several problems. First, countries had to agree on a common calendar to avoid that too many races are inefficiently run at the same time. Second, countries had to agree on systems of ranking for riders and teams, so that race organizers and notably the organizers of the World Championships can invite the world's best teams. Third, countries had to agree on certain disciplinary rules: what counts as a "bicycle" in a bicycle race, how is the winner determined, what counts as doping, etc. To solve these multiple coordination problems impartially, in 1900 the cycling federations of France, Belgium, Italy, Switzerland and the United States founded the International Cycling Union (UCI, after its French initials), the governing body of cycling. Although other non-governmental international associations had already organized the first European (1886) and World (1893) track championships and the first road cycling competition of the Olympic Games (1896), the UCI has been by far the most important governing body of cycling. Between 1965 and 1992, while Eastern-European Communist countries and the International Olympic Committee wanted to give more importance to amateur cycling, the UCI was split between the International Amateur Cycling Federation and the International Professional Cycling Federation (FIAC and FICP, after their French initials). Since then, however, the UCI is the sole governing body of cycling. Below we focus on three specific responsibilities of the UCI: the organization of a cycling calendar, the creation of a world ranking system and the set-up of race rules and anti-doping regulations. For a more detailed discussion of the overall organizational structure of professional cycling, we refer to chapter 2 .

\subsection{The organization of the cycling calendar}

The UCI manages the cycling calendar, which is composed of different types of races (table 1.2). The classics are one-day races. Most of them are run in spring or in autumn in Belgium, 
Italy and France. The five most prestigious classics, sometimes called the "Five Monuments of cycling”, are Milan-San Remo, the Tour of Flanders, Paris-Roubaix, Liège-Bastogne-Liège and the Tour of Lombardy. Each of these races is in some sense unique, whether because of its cobbled sectors, its hilly sections or other characteristics. Only three champions (Roger De Vlaeminck, Rik Van Looy and Eddy Merckx), all of them Belgians, have won all five of these races. The Grand Tours are three-week stage races which are run in spring or in summer in France (Tour de France), Italy (Giro d'Italia) and Spain (Vuelta a España). They are the most lucrative races of the cycling calendar. Only five champions (Jacques Anquetil, Felice Gimondi, Eddy Merckx, Bernard Hinault and Alberto Contador) have won all the Grand Tours. In contrast with the classics and the Grand Tours, which are organized by private companies and are run among sponsored teams, the Road Cycling World Championships are organized by the UCI itself, and they are run among national teams. As the World Championships are raced at the end of the cycling season, they do not always attract the best riders, who might feel tired after a long and hard season. Therefore, the World Championships are not as prestigious as the Grand Tours, but they are still among the most important races of the cycling calendar. The reigning World Champion wears the coveted rainbow jersey.

Road cycling being an outdoor sport, the period of the year when a race is run has a profound impact on the conditions under which it is run. While the Giro is run in spring, sometimes in cold, rainy or snowy conditions (the epic $14^{\text {th }}$ stage of the 1988 Giro with the legendary ascent and descent of a snow-covered Gavia pass, is just one extreme example), the Tour is run in summer, usually under hot weather. The cycling calendar is also one major reason why, among the Grand Tours, the Tour de France is more prestigious than the Giro d'Italia, which in turn is more prestigious than the Vuelta a España. As the Tour was created first, it could act as the leader firm, like in the Stackelberg model well-known in industrial economics theory. The Tour organizers chose to run the race in July, when relatively many Europeans are on holidays and there are relatively few alternative sport events: there is no soccer or rugby, only the Wimbledon tennis tournament. From the start, this guaranteed the Tour de France a relatively high audience, which, along with the French public's initially higher living standard than Italy or Spain's, enabled the Tour to reap relatively high revenues and thus attract the world's best riders. The Tour being a three-week, exhausting race it was not possible for other Grand Tours to choose to be held in August, because most riders would have skipped a threeweek race right after the Tour and the most lucrative criteriums were organized in August, especially from the 1950s to the 1980s. The spring classics being run until April, it was not 
possible either for other Grand Tours to choose to be held in April or earlier, because many riders would have preferred to ride the classics. This is why since 1909 the organizers of the Giro chose to run the race before the Tour, in May or June, and from 1935 to 1994 the organizers of the Vuelta chose to run it in April or May, even though in these months fewer spectators are on holidays and there are many other sport events. Until the 1990s it was common for certain champions to skip the Vuelta to be in better shape for the Giro or to skip the Giro to be in better shape for the Tour. From 1992 to 1995, one of the greatest Spanish riders of all time, Miguel Indurain, skipped the Vuelta to be better prepared for the Tour, as Federico Bahamontes had done more than thirty years before. Until the 1990s, it was not uncommon either for riders to ride the Vuelta not to win it but to prepare for the Giro, as Giuseppe Saronni openly admitted in 1983 , or to ride the Giro to prepare for the Tour.

In the early 1990s, however, the UCI aimed at moving a Grand Tour from congested spring to September, in order to lengthen the racing season, increase sponsors' media coverage and thereby increase sponsors' investments in cycling. While the Giro refused, the Vuelta accepted. Instead of skipping the spring race or considering it as a mere preparation for another race, riders could now ride the Vuelta in September to redeem or crown their season, or to be selected for the World Championships. By attracting more prestigious riders and gaining more TV coverage, this reform undoubtedly increased the attractiveness, prestige and economic value of the Vuelta, even though it is sometimes still considered to be no more than a preparation for the World Championships. For example, in 2000, fourth-place Jan Ullrich quit the Vuelta to prepare for the Olympic Games and in 2007, points-jersey holder Oscar Freire did the same to prepare for the World Championships. 
Table 1.2 Most important cycling events in professional road cycling

\begin{tabular}{|c|c|c|c|c|c|c|c|c|}
\hline & & & Name & Nickname & $\begin{array}{c}\text { Date of } \\
\text { Creation }\end{array}$ & $\begin{array}{l}\text { Position in the } \\
\text { calendar }\end{array}$ & Country & $\begin{array}{l}\text { Present (or Last) } \\
\text { Organizer }\end{array}$ \\
\hline \multirow{11}{*}{ Classics } & \multirow{7}{*}{ 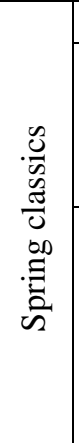 } & & Milan-San Remo & La Primavera (the spring) & 1907 & March & Italy & RCS \\
\hline & & \multirow{3}{*}{$\begin{array}{ll}\frac{0}{0} & 0 \\
\frac{0}{0} & .0 \\
0 & 0 \\
0 & \frac{\pi}{0}\end{array}$} & Gent-Wevelgem & & 1934 & March & Belgium & Flanders Classics \\
\hline & & & Tour of Flanders & Vlaanderens mooiste (Flanders' finest) & 1913 & April & Belgium & Flanders Classics \\
\hline & & & Paris-Roubaix & $\begin{array}{l}\text { La reine des classiques (Queen of classics) } \\
\text { or } L \text { 'enfer } d u \text { Nord (The hell of the North) }\end{array}$ & 1896 & April & France & ASO \\
\hline & & \multirow{3}{*}{ 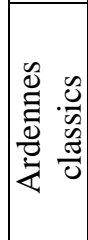 } & Amstel Gold Race & & 1966 & April & The Netherlands & $\begin{array}{l}\text { Amstel Gold Race } \\
\text { Foundation }\end{array}$ \\
\hline & & & La Flèche Wallonne & & 1936 & April & Belgium & $\mathrm{ASO}$ \\
\hline & & & Liège-Bastogne-Liège & La doyenne (the doyenne) & 1892 & April & Belgium & ASO \\
\hline & \multirow{4}{*}{\multicolumn{2}{|c|}{ 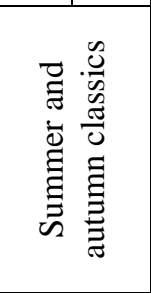 }} & Clásica San Sebastián & & 1981 & August & Spain & $\begin{array}{c}\text { Organizaciones Ciclistas } \\
\text { Euskadi } \\
\end{array}$ \\
\hline & & & Paris-Tours & $\begin{array}{c}\text { La course des lévriers (the greyhounds' } \\
\text { race) }\end{array}$ & 1896 & October & France & ASO \\
\hline & & & Tour of Lombardy & $\begin{array}{l}\text { La classica delle foglie morte (the classic } \\
\text { of the falling leaves) }\end{array}$ & 1905 & October & Italy & RCS \\
\hline & & & Milano-Torino & & 1876 & October & Italy & RCS \\
\hline \multirow{3}{*}{\multicolumn{3}{|c|}{ Grand Tours }} & Tour de France & La Grande Boucle (the Great Loop) & 1903 & July & France & ASO \\
\hline & & & Giro d'Italia & & 1909 & May & Italy & RCS \\
\hline & & & Vuelta a España & & 1935 & September & Spain & Unipublic / ASO \\
\hline \multicolumn{4}{|c|}{ World Championships } & & 1927 & $\begin{array}{c}\text { September or } \\
\text { October }\end{array}$ & Changing & UCI \\
\hline
\end{tabular}

Note: the table leaves aside races which no longer exist, e.g. the Grand Prix des Nations (1932-2004) or Bordeaux-Paris (1891-1988), and many races which still exist, such as one day classics as Paris-Bruxelles (created in 1893 and now called the Brussels Cycling Classic), or one-week stage races such as Paris-Nice (created in 1933, nicknamed La course au soleil, the race to the sun), Tirreno-Adriatico (created in 1966), the Tour of the Basque country (created in 1924), the Tour de Romandie (created in 1947), the Volta a Catalunya (created in 1911), the Critérium du Dauphiné libéré (created in 1947) or the Tour of Switzerland (created in 1933). 


\subsection{The creation of a world ranking system}

The UCI also manages the ranking system which determines the world's best teams and riders of the year, based on their season-long results. Until 1988, the (unofficial) ranking systems were established independently from the UCI: several newspapers (L'Équipe, La Gazzetta dello Sport, Het Nieuwsblad-Sportwereld and Les Sports) first managed the "DesgrangeColombo Challenge" (1948-1958) and then the spirits company Pernod managed the "Super Prestige Pernod International" (1959-1988). It is only since 1989 that the UCI ranking system prevails, under the names of "UCI World Cup" (1989-2004), "UCI Pro Tour" (20052008) and "UCI World Tour" (since 2011). One purpose of the UCI reform of the ranking system was to increase competition and to reduce collusion among riders and teams. Indeed, riders have to accumulate UCI points all year long to be allowed to participate in the most prestigious and best-paying races. This reduces a rider's incentive to "sell" certain races, because UCI points are highly valuable both to themselves (they directly increase their value, i.e. their wage) and to their team (they enable it to participate in those races where the sponsor gets the most media coverage). Another purpose of the UCI ranking system is to globalize cycling, by having non-European riders and teams participate in Western races and by including non-Western-European races in professional road cycling's calendar. This was expected to increase the quality of the show and bring additional (TV) spectators and commercial sponsors to cycling. In fact, the previous ranking systems already ranked riders according to their results in bicycle races all over European countries, which effectively made it in riders' interest to race abroad, thus contributing to the early globalization of cycling.

In 2005 the UCI decided that the World Cup would become a closed league under the name of UCI ProTour (see chapter 2). The 20 teams owning a four-year license had both the right and the obligation to participate in each of the then 27 annual ProTour races. Such organization effectively guaranteed team sponsors a high degree of media visibility for four years, which made them increase their investments in cycling. However, the UCI decided that the Pro Tour included not only classic races but also the Grand Tours, which means that the Tour, the Giro and the Vuelta now had to select the best-ranked ProTour teams instead of having teams pay to participate. Therefore, although the UCI ProTour garnered the support of team sponsors (because it made their return on investment more predictable) and riders (because it increased their wages and the duration of their labor contracts), the UCI Pro Tour was opposed by the organizers of the Grand Tours. 
In the negotiations that ensued between 2005 and 2008, Grand Tour organizers threatened the UCI with refusing to invite ProTour teams in their races and with organizing another cycling league, while the UCI threatened Grand Tour organizers with not letting ProTour teams participate in their races. More credibly, the UCI threatened Grand Tour organizers with replacing the Grand Tours with other races in the official calendar and with selling the organization of new bicycle races in China, Russia or South America to other sport companies. Although analyses of the more recent negotiations would be needed, the UCI and Grand Tour organizers now seem to have reached a compromise. Grand Tours will invite UCI Pro/World Tour teams plus four wildcards and not create another cycling league, UCI guarantees Grand Tours' positions in the cycling calendar and Grand Tour organizers may somehow be favored to organize new cycling competitions around the world.

\subsection{The set-up of race rules and anti-doping regulations}

The UCI also establishes the rules of bicycle races. Certain rules concern the equipment. Bicycle wheels' minimal and maximal diameters and minimal number of spokes, bicycle frames and forks' characteristics, etc. Equipment-related rules turned out to be particularly important in the history of the (track) World Hour record, which since 2000 included two records depending on the type of machine racers were riding when they set a record. In 2014, however, the UCI again unified the two classifications into a single classification in line with regulations for current track pursuit bikes. This change in the rules caused an upsurge in World Hour record attempts. Between September 2014 and February 2015 no less than five riders took on the challenge: Jens Voigt (new record), Matthias Brändle (new record), Jack Bobridge (failure), Rohan Dennis (new record) and Thomas Dekker (failure). But equipment rules are also important concerning road races. While derailleur gears were invented as early as the 1890s, their use was prohibited until the 1933 Giro and the 1937 Tour, to make these epic races more difficult and more spectacular. Other UCI rules concern races themselves, including the maximum number of stages or total length of a stage race.

Although the basic principles of bicycle races might seem simple, the history of the Grand Tours' rules shows that many different rules may apply. Some rules determine which riders and teams may participate. Riders were not allowed to group into teams in many of the early Tours (1903-1909, 1919-1924), because Tour organizers believed teams and mutual help 
made the race less heroic. This is also the reason why until the late 1920s Tour teammates were not allowed to help each other to repair their broken material and until 1938 independent riders were not allowed to help each other in any way. By contrast, since the 1937 Tour, the 1947 Giro and the 1950 Vuelta, riders are not allowed to participate unless they are members of a team. Race organizers do no longer need unsponsored riders to fill the peloton. As we saw, sponsored teams have also been excluded from the Tour for a long time (1930-1961, 1967-1968), because Tour organizers believed they tended to collude to share the prize pool instead of fighting for it.

Other rules determine which rider is the winner. The general classification ranking was decided by a points system in certain early Tours (1905-1912) and Giri (1909-1913), i.e. a rider's final ranking was determined by his cumulative ranks in each stage. By contrast with a time system where a rider's final ranking is determined by his cumulative time, the points system was easier and less costly to calculate and monitor. However, it was soon abandoned because it did not motivate riders: if all that counts in a stage is your rank, not your time, why fight to minimize your delay? While the general classification leader's jersey is yellow in the Tour (since 1919) and pink in the Giro (since 1931), after the color of L'Auto and La Gazzetta dello Sport, respectively, the Vuelta's leader's jersey had a more complex history. It has been orange $(1935,1942,1977)$, white (1941), white with a red stripe (1945-1950), yellow (19551976, 1978-1997), gold (1998-2009) and red (since 2010). Still other rules determine which types of stages are included in the race. Mountain stages have been included since the 1910 Tour and the 1909 Giro. Individual time trials date back to the 1934 Tour, the 1933 Giro and the 1941 Vuelta and prologues to the 1967 Tour, the 1968 Giro and the 1969 Vuelta. Team time trials are run since the 1927 Tour and the 1937 Giro. Besides the general classification, Grand Tours also reward the best climber's king-of-the-mountain's classification since the 1933 Tour and Giro and the 1935 Vuelta and the best sprinter's points classification since the 1945 Vuelta, the 1953 Tour and the 1966 Giro.

It should be noted that, as was clear from the discussion, most of these rules were defined by the Grand Tour organizers themselves, and not by the UCI. Still today, the power struggle between race organizers and the UCI (and in some cases the teams) on race regulation issues continues. In the past couple of years, this has been made clear on numerous occasions, for instance, in the discussion on the use of radio communication during the race. 
The UCI also establishes anti-doping rules. As is described in detail in chapter 13, road cycling and doping have a long history. Already before World War II, riders used strychnine, cocaine and morphine. From the 1950s, they also used amphetamines, and each rider could easily detect who was taking "la bomba" (Fausto Coppi's words to describe doping), by looking at which riders had dilated pupils and kept drinking. From the 1970s, riders started using steroids and corticoids, notably cortisone. And from the 1990s, most riders used Erythropoietin (epo) and growth hormone, which contrary to previous forms of doping require medical monitoring. In the 1990s and 2000s doping riders' doctors sometimes earned a share of the riders' prizes, which is part of the reason why it was in their interest to optimize riders' doping. Riders' pervasive doping practices have long gone along with a silence code: when champions Fausto Coppi, Jacques Anquetil, Bernard Thévenet and José Manuel Fuente admitted to doping (respectively in the 1950s, 1960s, 1970s and 1990s), they scandalized most riders. And after Filippo Simeoni admitted he had taken epo and growth hormones, an outraged Lance Armstrong personally prevented him from breaking away from the peloton on the $18^{\text {th }}$ stage of the 2004 Tour, "to protect the interests of the peloton." More on the history of doping in cycling can be found in Woodland (2003).

In 1960, two doping tragedies occurred. In the 1960 Tour, French champion Roger Rivière had a very serious accident after his amphetamines and painkillers prevented him from using his brakes. He broke his backbone and never rode a bicycle again. And a few weeks later, in the 1960 Olympic team time trial, Danish rider Knut Jensen died because of doping. As a result, already in 1960, the UCI incorporated an article about doping in its regulations. Previously, doping did not exist as a prohibited practice. A couple of years later, in 1966, the UCI was the first international federation to devote an entire chapter on doping in the regulations and the first to have urine samples analysed. Much later, the UCI was the first major sports association to make its athletes take blood tests for scientific research in 1996. In 2007, the UCI was the first federation to apply a blood passport and in 2011 once again the UCI was the first federation to establish a no-needle policy before, during and after races. Still, in spite of all this efforts the UCI faces an image of failure when it comes to fight doping. This is, among other reasons, because it was long technically difficult to detect certain doping or masking substances. As a result, devising and organizing anti-doping controls was (and still is) very expensive. Furthermore, until at least the 1980s, most riders knew in advance when they would take an anti-doping test so they stopped doping temporarily or they took masking drugs. And from the late 1990s, when the UCI lacked a test for epo and set 
riders' hematocrit ceiling at 50\%, the perverse effect of this rule was that riders wanting to be competitive doped themselves until they reached the ceiling. It is only since the late 2000 s that anti-doping controls have become unpredictable and that doping seems to be fought more successfully by the UCI (Zorzoli and Rossi 2010).

\section{The show of bicycle races: a century of 'Grand Tours'}

Since the late $19^{\text {th }}$ century, bicycle races did not just globalize: the show changed in several other respects. Organizers adapted the Grand Tours to the public's demand, which helps explain professional cycling's enduring success.

\subsection{National passions: the Grand Tours' background}

Many bicycle races are century-old institutions which have become symbols of national identity. The Tour de France, the Giro d'Italia and the Vuelta a España, but also the Tour of Flanders and the Clásica San Sebastián, all tend to cultivate their nationalist overtone. After winning the 1970 Vuelta, Spanish rider Luis Ocaña, who lived in France and was nicknamed "el francés" (the French guy) by the Spanish press, declared: "Today I feel more Spanish than ever." The 1989 Tour offered 17,890 Francs at the $1,789^{\text {th }}$ kilometer to celebrate the $200^{\text {th }}$ anniversary of the French Revolution, and the 1994 Tour went through the places where the Normandy landings liberated France from the Nazi occupation 50 years before. Similarly, the 1911 Giro started in Rome (instead of Milan) to celebrate the $50^{\text {th }}$ anniversary of Italy's political unification, and the 1961 Giro went through the island and cities that played a role in Garibaldi's struggle to unify Italy 100 years before. In this patriotic context, it is no wonder that rivalries between riders from different countries sometimes degenerated into rivalries between supporters from different countries or between different countries themselves, especially since it was often in an organizer's interest to inflame nationalist passions in order to increase their sales.

Foreign riders have had conflicts with race organizers, whom they accused to be biased against them. The general classification leader Sylvère Maes, a Belgian, quit the 1937 Tour to protest against what he — understandably — saw as a biased enforcement of the rules. The Italian teams also quit the 1950 Tour to protest against organizers' incapacity to protect Gino Bartali's physical security, although Bartali's goal might also have been to deprive fellow 
countryman and rival Fiorenzo Magni from the general classification leadership. The Giro organizers have long established the race's route to make a specific Italian rider win. They increased the importance of the mountain stages and decreased that of individual time trials to make Gino Bartali win in 1937 and did exactly the opposite to make Francesco Moser win in 1977, to make Giuseppe Saronni win in 1981, and to make Moser or Saronni win in 1979, 1983 and 1984. The latter Giro is notorious for the "injustice" done to French rider Laurent Fignon. The race organizers cancelled without good reason a hard mountain stage (the ascent of the Stelvio Pass), they did not punish Moser for being pushed by supporters and for riding in the shelter of the caravan cars during another hard ascent, and they placed helicopters so as to slow down Fignon and help Moser in the final time trial. By contrast, the Vuelta organizers have long favored foreigners to induce more of them to participate. They paid foreign stars to participate (e.g. Raymond Poulidor in 1967), they established the race's route to favor them (e.g. Louison Bobet and Hugo Koblet in 1956, Rik Van Looy and Roger Rivière in 1959, Freddy Maertens in 1977), and they sometimes even enforced the rules to the detriment of Spanish riders (e.g. José Pérez Francés 1962). Foreign riders also had conflicts with the organizing country's supporters. In the 1910 Giro, French rider Jean-Baptiste Dortignacq's victory in the $2^{\text {nd }}$ stage led angry Italian supporters to attack foreign racers. In the 1975 Tour, general classification leader Eddy Merckx was punched in the stomach by a French fan of Bernard Thévenet. Foreign riders also had direct conflicts with the organizing country's riders. In the 1912 Tour Belgian riders coalesced to make Belgian champion Odile Defraye win. In the 1935 Vuelta Spanish riders coalesced to help Mariano Cañardo win. And in the 1985 Vuelta Spanish riders coalesced against Scottish rider Robert Millar.

In addition, in times of international tensions, bicycle races sometimes took a political turn. Foreigners did not participate in the 1911 or 1936 Giro, because Italy was engaged in colonization wars in Libya and Ethiopia, respectively. Foreigners did not participate in the 1946 Giro either, because formally Italy was still at war against most other cycling nations. Similarly, Italians did not participate in the 1936 Tour and Germans, Italians and Spaniards did not participate in the 1939 Tour. The Italian Fascist government directly used the Giro as a means of propaganda. The 1927 Giro's prize pool was increased by 25,000 lire by Italian leader Benito Mussolini himself. In the 1930s, the general classification leader's jersey included the Fascist emblem and in 1938, the Fascist government ordered Gino Bartali to skip the Giro to win the Tour, which he did. After the war, in 1947, the Tour organizers did not invite German riders: the memories of Nazi occupation were too fresh. The 1963 Vuelta 
started in Mieres, an Asturian city where the year before miners had organized a strike which Franco's government brutally repressed. Thus, the race's start was supposed to prove the government's authority over the country.

Bicycle races and the twentieth-century wars

The $20^{\text {th }}$-century wars affected bicycle races in several ways. First, wars cancelled several races. The first World War cancelled the Tour and the Giro (1915-1918), as well as the five monuments except the Tour of Lombardy. The Spanish civil war cancelled the Vuelta (19371940). The second World War cancelled the Tour (1940-1946), the Giro (1941-1945), the Vuelta (1943-1944) and the five monuments except the Tour of Flanders. Indeed, bicycle races could not be run in wartime because organizers lacked gasoline, food and tires, but also because roads were destroyed. It is these war devastations which led journalists to call the 1919 Paris-Roubaix the "hell of the North." Nevertheless, in a war-devastated country, Francisco Franco's government organized the 1941 Vuelta to give the population an illusion of normality, the only foreign participants came from neutral Switzerland.

Second, wars personally struck several riders. The first World War killed Tour winners François Faber, Octave Lapize and Lucien Petit-Breton, as well as 1913 Giro winner Carlo Oriani. At the end of the Spanish civil war, Julián Berrendero, the future winner of the 1941 and 1942 Vueltas, was imprisoned in a concentration camp for eighteen months. In reaction to such tragedies, riders sometimes mobilized. The Spanish riders from the 1937 Tour de France gave half of their earnings to Spanish war orphans.

Finally, postwar times led Grand Tour organizers to go through cities and places which their country claimed as theirs. The 1919 Tour went through Strasbourg and Metz, two cities of the region of Alsace-Lorraine, which France had recuperated following the first World War. Similarly, the 1946 Giro went through the disputed city of Trieste (which became Italian only in 1954), thus angering the Slovene minority and causing riots for several days.

Although bicycle races may set national rivalries on fire, they also have long dramatized within-country rivalries. In the early Grand Tours, regional divisions were salient. The public identified racers by their region or city of origin: the best Italians came from Piedmont and the best Spaniards came from the Basque country. Local supporters often threw nails on the roads to favor the local rider. The 1932 Tour made the Belgian team's divisions among French- and Flemish-speaking Belgians clear. Later, from the 1940s to the 1960s, the Italian public was deeply divided between supporters of Gino Bartali and Fausto Coppi ("Bartaliani" and "Coppiani"), the French public was also divided between supporters of Jacques Anquetil and Raymond Poulidor ("Anquetiliens" and "Poulidoristes") and the Spanish public was divided between supporters of Jesús Loroño and Federico Bahamontes ("Loroñistas" and "Bahamontistas"). While the attempted assassination of the Italian Communist leader in 1948 led to a general strike in Italy, head of state Alcide de Gasperi phoned Gino Bartali, who was 
racing the Tour de France, to ask him to win the race and unify his countrymen. Political activists also used the Grand Tours to pressure the government or to popularize or otherwise promote their cause. Striking workers blocked the $16^{\text {th }}$ stage of the 1969 Giro, the $5^{\text {th }}$ stage of the 1982 Tour, the $14^{\text {th }}$ stage of the 1980 Vuelta and the prologue of the 1983 Giro. Most importantly, the Basque separatist movement ETA, which conceived the Vuelta a España as a Spanish invasion of its Basque homeland, sabotaged the last stage of the 1967 race. It bombed the road in the $15^{\text {th }}$ stage of the 1968 race and it sabotaged again the race's route in 1977 and 1978 before assassinating several people during the 1981 Vuelta and bombing the $16^{\text {th }}$ stage of the 1990 Vuelta. That is why the Vuelta stopped going through the Basque country from 1979 to 2011 and the Basque newspaper organizing the Vuelta from 1955 on stopped doing so in 1979, even while the Basque country had been the Vuelta's most important region until then. Basque separatists also bombed several teams' material in the $18^{\text {th }}$ stage of the 1974 Tour. On the day of the $12^{\text {th }}$ stage of the 1974 Giro, a right-wing bombing killed six people. In 1974 also, the Red Brigades assassinated Emilio Bozzi, the owner of the Legnano bicycle company, which had sponsored Alfredo Binda, Gino Bartali and Fausto Coppi.

\subsection{Epic races: Grand Tours' difficulty}

Although Grand Tour organizers have kept finding ways to maintain or increase their races' epic character, many aspects of these races have changed over time, including their difficulty. While the number of Grand Tours' participants varied between 50 and 150 until the early 1980 s, since the 1990 s it is closer to 200 , the maximum number of riders in a race according to UCI regulations. In this respect, the 1926-1928 Giri, which included up to 300 riders, notably "isolati" riders related to political and military groups, were an exception.

Since the early $20^{\text {th }}$ century, each of the three Grand Tours lasts three weeks, but the number of racing days has increased substantially to the detriment of rest days. The very first Tours included less than ten racing days and at least one rest day per racing day, and until the mid1920s the Tour and the Giro still included less than 15 racing days and almost one rest day per racing day. Nowadays, the Grand Tours include 21 racing days and less than 0.1 rest day per racing day. In this sense, it would seem that, as cycling professionalized, the Grand Tours became more physically demanding. 
However, as can be seen from figure 1.3, at the same time the mean distance per racing day strongly decreased, first abruptly in the 1920s (from around 350 kilometers to around 200 kilometers), and then continuously since the 1930s (from around 200 kilometers to around 160 kilometers today). This reflects organizers' anticipation of the public's changing demand. Until the 1920s, when bicycles were a symbol of speed and modernity, the public wanted to read about long stages in which riders defied the forces of nature, staggeringly long distances and durations, mountains, rain and snow. In addition, the Grand Tours' sponsors wanted to prove the quality and resistance of their material in very hard conditions. The length of the stages required that riders start racing late at night or very early in the morning, so that they arrive in the afternoon and journalists could tell the story of the stage the day after. This was the time when Eugène Christophe won the $5^{\text {th }}$ stage of the 1912 Tour after a $315-\mathrm{km}$ breakaway, when Clemente Canepari won the $7^{\text {th }}$ stage of the 1913 Giro after a 236-km solo breakaway, and when Lauro Bordin did not win the $3^{\text {rd }}$ stage of the 1914 Giro despite a 350km breakaway.

Fig. 1.3 Mean distance (in kilometer) per racing day in the 'Grand Tours' (1903-2013)

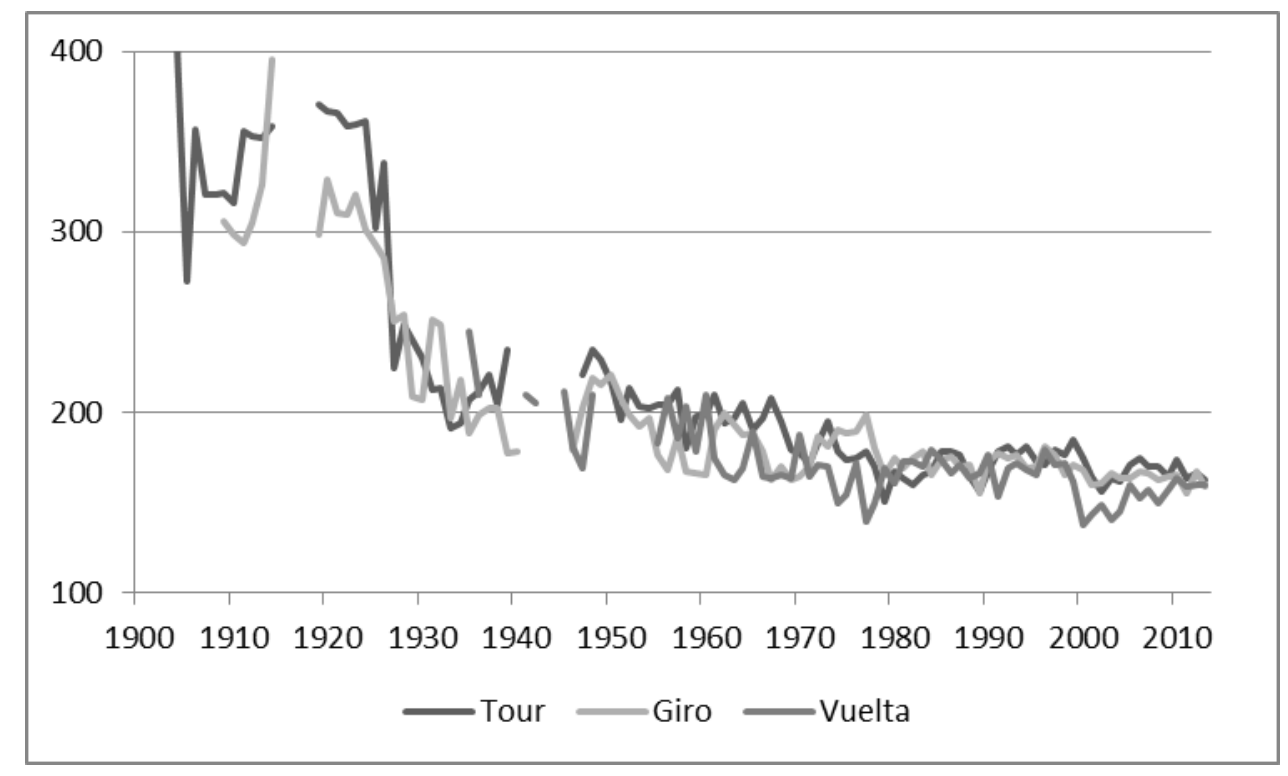

Sources: A.S.O. (Tour de France); RCS Sport and Castellano Carmine (Giro d'Italia); Unipublic (Vuelta a España).

In the 1920s, when the Grand Tours started being broadcast on the radio, the public wanted to follow the race live, which given the limited radio time required more nervous, hence shorter, stages. In turn, the shortening of stages enabled organizers to increase the number of stages. In the 2000s, the mean distance per racing day has been relatively shorter in the Vuelta than in 
the other two Grand Tours, perhaps partly because the Vuelta is now raced at the end of the cycling season. If organizers want to have a nervous race despite riders' tiredness, they need to organize relatively short stages. Therefore, as the media through which the public came to follow the Grand Tours changed, the public's demand changed and organizers adapted. Grand Tours went from epic races with a few nonconsecutive but very long stages to other types of epic races with many consecutive but shorter stages.

\subsection{Epic fights: riders' performance and Grand Tours' competitiveness}

As Grand Tours' difficulty changed, riders' performances increased. Not only did their quit rate decrease, their mean speed also increased. While the early Grand Tours were deliberately very hard to finish (until the late 1920s around $75 \%$ of participants failed to finish races), riders' quit rate declined abruptly in the 1920s (from about $75 \%$ to about 50\%), and it declined continuously since the 1930 s (from around $50 \%$ to around $20 \%$ today). This likely reflects the 1920s drop in the mean distance per racing day, as well as the multiple ways which have made riders' lives and careers easier since the 1930s. At the same time, riders' speed increased, as the winners' mean speed since the 1930s illustrates in figure 1.4. This reflects major long-term changes in the quality of riders' equipment, road quality and bicycle weight. Riders' increasing speed also reflects changes in the rules of bicycle races. Until the 1930s, Giro riders had to repair their damaged bicycles, i.e. they were not allowed to replace them with new material, and Tour riders even had to perform those repairs without any help. And until the 1930s riders were not allowed to use derailleur gears, which made them go slower in both ascents and descents. Riders' better physical preparation (diet, training and doping) also probably had an impact on their performances. A similar increase in riders' speed is observed in the classics, in which distances have remained (broadly) constant over time. Typical race average speeds in the early twentieth century were often below 30 kilometers per hour while typical modern events exceed 40 kilometers per hour.

However, the interest of professional road cycling depends less on riders' performance than on competitive balance and outcome uncertainty. The time difference between the winner and the second-best rider, which is one indicator of competitive balance, steeply declined from the 1920 s to the 1930 s, and then from the 1950 s to the 1960s. As a result, while gaps of 30 minutes or more were common until the 1920s, typical gaps are less than 3 minutes today. It is no wonder, then, that the closest victories did not occur earlier than the 1948 Giro (11 
seconds), the 1984 Vuelta (6 seconds) and the legendary 1989 Tour (8 seconds). Fuller analyses of the long-term evolution of Grand Tours' competitive balance should complement this simple approach to individual "competitiveness" with indicators based on teams', not just riders' performances (Andreff 2013).

Fig. 1.4 Winner's mean speed in the 'Grand Tours' (1903-2013)

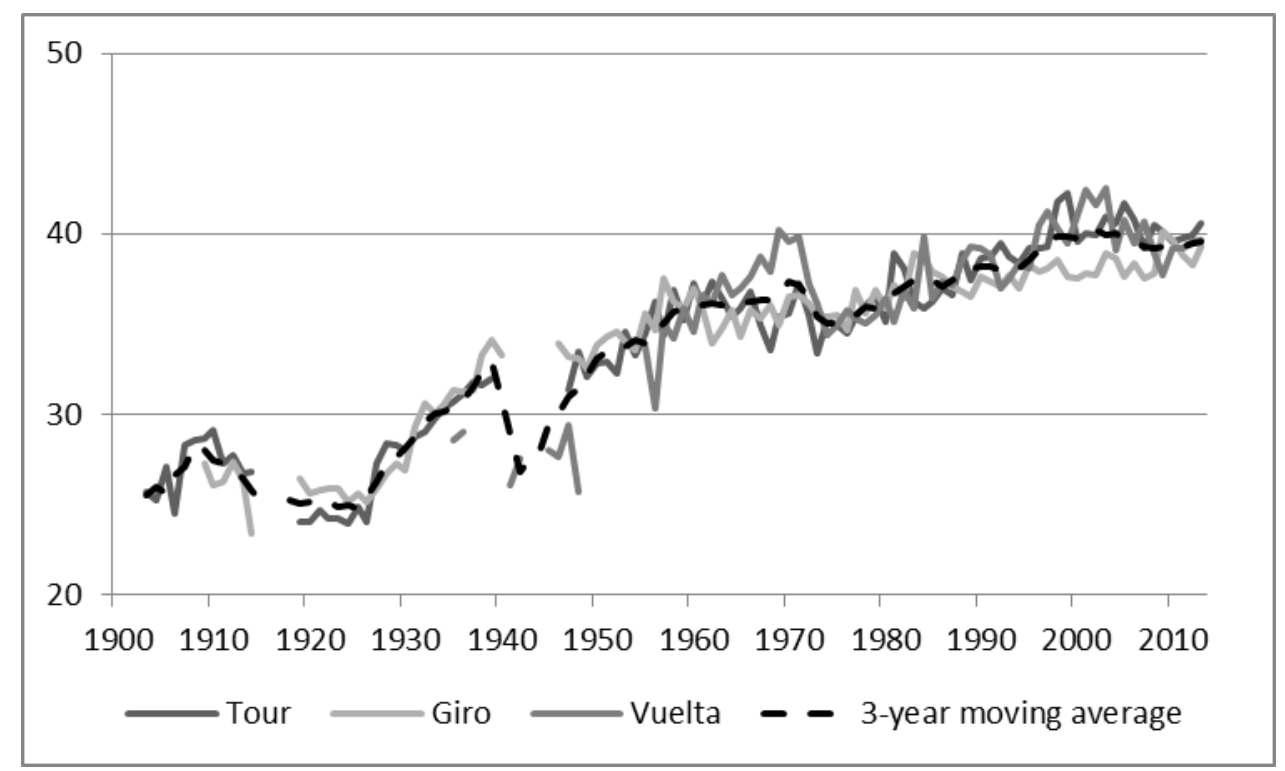

Sources: A.S.O. (Tour de France); RCS Sport and Castellano Carmine (Giro d'Italia); Unipublic (Vuelta a España).

Obviously, race organizers know better than anyone else that competitive balance is a major determinant of the success of a race, and they have long struggled to maintain or increase it. After il campionissimo Alfredo Binda had already won the 1925, 1927 and 1928 Giri (in 1927 he won 12 out of 15 stages and was leader from the beginning to the end), he won 8 consecutive stages and the whole 1929 race, and the crowd booed him. This is why the following year the Giro organizers paid him 22,500 lire, i.e. the equivalent of the general classification victory and several stage victories, so that he did not participate in the 1930 Giro. And the same year, the Tour organizers had to give him start money to convince him to participate in the Tour. When in 1934 Tour organizers included the king-of-the-mountains classification, they also organized the first individual time trial so that not only climbers but also riders who are strong on the flat may win the race. In the 1952 Tour, race organizers included a fighting-spirit prize for the rider who attacks the most and when the campionissimo Fausto Coppi dominated the race as early as the $10^{\text {th }}$ stage, organizers doubled the secondplace cash prize so that riders fight for second if not first place. Similarly, Merckx's absolute 
domination over professional road cycling in the early 1970s made him relatively unpopular not only among a jealous peloton, but also among non-Belgian spectators who felt he decreased races' interest, and perhaps also among broadcasters. Merckx's astounding domination may have been one reason why the Italian TV stopped broadcasting the Giro live from 1972 to 1975.

The analysis of cycling performances will be discussed in detail in chapter 12. Interested readers could also consult Torgler (2007), Prinz and Wicker (2012) and Rogge et al. (2013).

\section{Conclusion}

As most economic sectors, since the late $19^{\text {th }}$ century professional cycling has benefitted from increasing labor division. Amateur bicycle racers now become professionals at a younger age than a century ago. They do no longer need to keep some other, more predictable job along with their sport career. Since the 1930s, professional riders have also been specializing into certain roles in their team, whether it be sprinters, flat riders or climbers. Most riders are domestiques whose main role is to help their team leader win. The observed increase in performance inequality among Tour de France riders since the 1970s is entirely due to an increase in performance inequalities within, not between teams (Candelon and Dupuy 2010), which means that domestiques sacrifice their own chances more and more to help their team leader win and then share his prizes. Riders' physical preparation is also optimized. While the Italian campionissimo Fausto Coppi introduced a scientific approach to diet, training and equipment as early as the 1940s, it is only since the 1980s that science (biomechanics, aerodynamics, etc.) significantly contributes to performance. Finally, since the 1990s, starting with riders like Greg LeMond and Miguel Indurain, team leaders ceased to participate in most events of the cycling calendar. While some champions specialize in the classics, others specialize in 'Grand Tours'. Nowadays, teams' riders who specialize in the 'Grand Tours' are also grouped into squads (sub-teams) which adjust their yearly fitness peak to be best prepared for one specific 'Grand Tour'.

\section{References}

- Andreff W (2013) Economie du cyclisme : succès commercial et équilibre compétitif du Tour de France. In : Colloque Le Vélo et le Droit: Transport et Sport, Université du Havre, Le Havre, 3-4 October 2013 
- A.S.O., Augendre J (2013) Le Tour de France. Guide historique. Available via A.S.O. http://www.letour.fr/. Accessed 1 March 2014

- Bolotny F, Bourg J-F (2009) The demand for media coverage. In: Andreff W, Szymanski S (eds) Handbook on the economics of sport. Edward Elgar, Northampton, p 112-133

- Calvet J (1981) Le mythe des géants de la route. Presses universitaires de Grenoble, Grenoble

- Candelon B, Dupuy A (2010) Hierarchical Organization and Inequality in an Economy with an Implicit Market for Productive Time. IZA Discussion Paper. Available via http://ftp.iza.org/dp5391.pdf. Accessed 1 March 2014

- Chany P, Cazeneuve T (2003) La fabuleuse histoire du Tour de France. Minerva, Geneva

- Chany P, Penot C (1997) La fabuleuse histoire du cyclisme. La Martinière, Paris

- Dauncey H, Hare G (2003) The Tour de France, 1903-2003. A Century of Sporting Structures, Meanings and Values. Frank Cass, Portland

- Fallon L, Bell A (2013) Viva la Vuelta ! 1935-2013. Mousehold Press, Norwich

- Flanders Classics (2013) Available via http://www.flandersclassics.be/en. Accessed 1 March 2014

- Gaboriau P (1995) Le Tour de France et le vélo. Histoire sociale d'une épopée contemporaine. L'Harmattan, Paris

- Howard P (2008) Sex, Lies and Handlebar Tape. The Remarkable Life Of Jacques Anquetil, The First FiveTimes Winner Of The Tour De France. Mainstream Publishing, Edinburgh

- INSEE (1952) Annuaire statistique de la France 1951. PUF, Paris

- Maddison A (2004) The World Economy: Historical Statistics. OECD Development Center, Paris

- McGann B, McGann C (2012) The Story of the Giro d'Italia. A Year-By-Year History of the Tour of Italy. Volume Two: 1971-2011. McGann Publishing, Cherokee Village.

- McGann B, McGann C (2011) The Story of the Giro d'Italia. A Year-By-Year History of the Tour of Italy. Volume One: 1909-1970. McGann Publishing, Cherokee Village

- McGann C, McGann B (2008) The Story of the Tour de France vol. 2. Dog Ear Publishing, Indianapolis

- McGann C, McGann B (2006) The Story of the Tour de France vol. 1. Dog Ear Publishing, Indianapolis

- McKay F (2011b) The Man Who Sold the Tour. In: Cyclismas. Available via http://www.cyclismas.com/2011/09/the-man-who-sold-the-tou/. Accessed 1 March 2013

- McKay F (2011a). The Shadow of the Tour: The Post-Tour Critérium Circuit. In: Podium Cafe. Available via http://www.podiumcafe.com/2011/8/16/2365901/the-shadow-of-the-tour-the-post-tour-criterium-circuit. Accessed 1 March 2014

- Mignot J-F (2014) Histoire du Tour de France. La Découverte, Paris

- Prinz J, Wicker P (2012) Team and Individual Performance in the Tour de France. Team Performance Management 18:418-432

- RCS Sport (2013) Available via http://www.gazzetta.it/. Accessed 1 March 2014

- Reed E (2003) The Economics of the Tour, 1930-2003. In: Dauncey H, Hare G (eds) The Tour de France, 1903-2003. A Century of Sporting Structures, Meanings and Values. Frank Cass, Portland, p 103-127

- Rogge N, Van Reeth D, Van Puyenbroeck T (2013) Performance Evaluation of Tour de France Cycling Teams Using Data Envelopment Analysis. International Journal of Sport Finance 8:236-257

- Rosen S (1981) The Economics of Superstars. The American Economic Review 5:845-858

- Sandy R, Sloane P, Rosentraub M (2004) The Economics of Sport. An International Perspective. Palgrave McMillan, New York

- Thompson C (2006) The Tour de France: A Cultural History. University of California Press, Berkeley

- Torgler B (2007) "La Grande Boucle." Determinants of Success at the Tour de France. Journal of Sports Economics:317-331

- Tullock G (1980) Efficient Rent Seeking. In: Buchanan J, Tollison R, Tullock G (eds) Toward a Theory of Rent Seeking Society. Texas A\&M University Press, College Station, p 97-112

- Unipublic (2013) La historia de la vuelta ciclista a España. Available via http://www.lavuelta.com/. Accessed 1 March 2014

- Van Reeth D (2013) TV Demand for the Tour de France: the Importance of Stage Characteristics Versus Outcome Uncertainty, Patriotism and Doping. International Journal of Sport Finance:39-60

- Vigarello G (1997) The Tour de France. In: Nora P, Kritzman L (eds) Realms of Memory: The Construction of the French Past, vol. 2: Traditions. Columbia University Press, New York, p 469-500

- Woodland L (2003) The Crooked Path to Victory: Drugs and Cheating in Professional Bicycle Racing. Cycle Publishing, San Francisco

- Zorzoli M, Rossi F (2010) Implementation of the biological passport: the experience of the International Cycling Union. Drug Testing and Analysis 11-12:542-547 